\title{
Implementation of bundles in preventing infection after total hip arthroplasty
}

Implementação de bundles na prevenção da infeção após prótese total da anca Implementación de las medidas de prevención de infección después de la colocación de una prótesis total de cadera

Matilde Delmina da Silva Martins*iD; Alfredo Carlos Preto Fernandes**iD

Abstract

Background: Surgical site infections are among the most common healthcare-associated infections in hospitalized patients. Objective: To analyze the effectiveness of the measures implemented for preventing surgical site infections in patients undergoing total hip arthroplasty.

Methodology: Retrospective cohort study. The sample comprised all patients undergoing hip arthroplasty between 1 October 2014 and 31 September 2016. A grid was created to enter the data selected for the study, in compliance with the standard for prevention of surgical site infections and isolation of infectious agents from the Directorate-General of Health.

Results: In the sample of 214 participants, $56.1 \%$ were male patients, with a mean age of 71.04 years and $19.2 \%$ had diabetes. The overall rate of surgical site infection of $6.1 \%$ decreased by $28.4 \%$ after the implementation of prevention bundles.

Conclusion: The number of infections decreased after the implementation of the bundles, and thus their implementation is relevant.

Keywords: surgical wound infection; arthroplasty, replacement, hip; prevention

\section{Resumo}

Enquadramento: As infeçôes do local cirúrgico representam uma das mais frequentes infeçôes associadas aos cuidados de saúde em pacientes hospitalizados.

Objetivo: Analisar o efeito das medidas implementadas para prevenção da infeção do local cirúrgico em pacientes submetidos a colocaçáo de prótese total da anca.

Metodologia: Estudo de coorte retrospetivo. Amostra foi constituída por todos os pacientes submetidos a artroplastia da anca no período de 1 de outubro de 2014 a 31 de setembro de 2016. Elaborou-se uma grelha onde foram inseridos os dados selecionados para o estudo, em conformidade com a norma Feixe de Intervençôes de Prevenção de Infeção de local cirúrgico da Direção-Geral da Saúde. Resultados: Dos 214 participantes, 56,1\% eram do sexo masculino, com uma média de idade de 71,04 anos e 19,2\% apresentavam diabetes. Registou-se uma taxa global de infeçáo do local cirúrgico de $6,1 \%$, e uma diminuição de $28,4 \%$ após a implementação das bundles de prevenção.

Conclusão: Registou-se diminuição da infeção com a implementaçáo das bundles, sendo relevante a sua implementação.

Palavras-chave: infeção da ferida cirúrgica; artroplastia de quadril; prevenção

*Ph.D., Associate Professor, School of Health, Polytechnic Institute of Bragança, Health Sciences Research Unit: Nursing (UICISA: E), 3000-232, Coimbra, Portugal [matildemartins@ipb.pt]. (D) https://orcid.org/0000-0003-2656-5897. Contribution to the article: statistical data analysis, discussion of results, overall article revision.

**RN, Northeast Local Health Unit - Hospital Unit of Macedo de Cavaleiros, 5340-240, Macedo de Cavaleiros, Portugal [alfredopreto81@hotmail.com]. (D https://orcid.org/00000001-6891-6961. Contribution to the article: literature search; data collection; statistical treatment and evaluation; data analysis and discussion; article writing. Address for correspondence: Avenida Afonso V., 5300-121, Bragança, Portugal.

\section{Resumen}

Marco contextual: Las infecciones del sitio quirúrgico representan una de las infecciones más frecuentes asociadas a los cuidados de salud en pacientes hospitalizados.

Objetivo: Analizar el efecto de las medidas implementadas para prevenir la infección del sitio quirúrgico en pacientes sometidos a la colocación de una prótesis total de cadera.

Metodología: Estudio de cohorte retrospectiva. La muestra estuvo constituida por todos los pacientes sometidos a artroplastia de cadera en el período del 1 de octubre de 2014 al 31 de septiembre de 2016. Se elaboró un cuadro en el que se insertaron los datos seleccionados para el estudio, la información relativa al cumplimiento de las normas de la Dirección General de Sanidad para la prevención, el desarrollo de infecciones en el sitio quirúrgico y el agente infeccioso aislado.

Resultados: De los 214 participantes, el 56,1\% era del sexo masculino, con una media de edad de 71,04 ańos, y el 19,2\% presentó diabetes. Se registró una tasa global de infección del sitio quirúrgico del $6,1 \%$, así como una disminución del $28,4 \%$ después de implementar las medidas de prevención.

Conclusión: Se registró una disminución de la infección al implementar las medidas de prevención, por lo que se considera relevante utilizarlas.

Palabras clave: infección de la herida quirúrgica; artroplastia de reemplazo de cadera; prevención

Received for publication: 19.07 .18

Accepted for publication: 27.02.19 


\section{Introduction}

The health sector in Portugal has been undergoing profound changes over the past 30 years. With the evolution of healthcare, surgical site infections (SSIs) have become one of the most common Healthcare-Associated Infections (HAI).

In Portugal, according to the 2017 National Infection Prevalence Survey, the incidence rate of HAI was $7.8 \%$ and of SSIs after total hip arthroplasty (THA) was 1.8\% (Direção-Geral de Saúde [DGS], 2017). The SSI risk is associated with the type of surgical procedure. Patients with an SSI have a five-time higher risk of death, a $60 \%$ higher risk of being hospitalized in intensive care, and are five times more likely to be readmitted to the hospital (DGS, 2017). The objective of this study is to analyze the effectiveness of the measures implemented for preventing SSIs in patients undergoing total hip arthroplasty.

\section{Background}

The Centers for Disease Control and Prevention (CDC) definition of SSI is the most consensual one, despite being established in 1999, and is commonly used in the majority of studies. It identified the onset of the signs and symptoms of SSIs within 30 days after any operative procedure if no prosthesis in place. If a prosthesis is placed, the surveillance period for SSI is 1 year. The post-discharge period is of extreme importance to distinguish SSI from non-SSI cases (CDC, 2017).

According to the CDC, there are three types of SSIs depending on their location: superficial incisional infection (SII); deep incisional infection (DII), and organ/space infection (OSI; CDC, 2017).

Risk factors for SSIs depend on the external and internal factors that affect an organization. The complexity and dynamics of healthcare, as well as its vulnerabilities, are the result of complex interactions between health professionals, patients, technology, and the healthcare environment itself. Knowing the risk factors for infection contributes to its prevention.

The risk factors for SSIs associated with joint replacement are those related to the procedure: surgery longer than 2.5 hours; a higher number of professionals in the operating room (students/ professionals undergoing training); prosthetic revision; excessive blood loss requiring transfusion. The following unrelated factors increase the risk for SSI: alteration of the natural barriers for protection of the skin and mucous membranes; immunodeficiency; disease severity; associated diseases; weight; comorbidities; old age; and length of hospital stay (Shuman, Urquhart, \& Malani, 2012).

In addition to being a threat to patient safety, hospital-acquired infections are a major public health issue with a strong financial impact on the institutions and healthcare systems in general (Fundação Calouste Gulbenkian [FCG], 2015). Studies developed in the United States of America show that SSI contributed the most to overall costs $(33.7 \%)$, followed closely by ventilator-associated pneumonia (31.6\%), and central line-associated bloodstream infections (18.9\%; FGC, 2015).

Indeed, the implementation of measures for preventing this important public health issue has a significant impact on both morbidity and mortality in the inpatient setting, as well as on cost reduction. Several countries have developed interventions to mitigate this problem (FCG, 2015). In Portugal, some measures have also been taken to reduce SSI rates. In 2015, the DGS issued a standard establishing that: all patients undergoing surgery should shower with $2 \%$ chlorhexidine on day before or day of surgery, at least 2 hours before it; antibiotic prophylaxis should be administered within 60 minutes of a surgical incision, when indicated; hair should not be removed or, if absolutely necessary, should be removed with a clipper immediately before surgery; maintain perioperative normothermia (core temperature of $\geq 35.5^{\circ} \mathrm{C}$ ) and blood glucose levels $\leq 180 \mathrm{mg} / \mathrm{dl}$ during surgery and in the 24-hour period following surgery (DGS, 2015). Although SSIs can be very severe, they can be minimized if health professionals take prevention measures during the perioperative period. These measures are particularly important in case of prosthetics because of the use of non-organic material, which increases the risk of infection (DGS, 2015). 


\section{Research questions}

Is the SSI rate lower in patients undergoing THA when the surgical bundle protocol proposed by the DGS is applied?

What is the impact of age, diabetes, and obesity on the development SSI?

What are the characteristics of SSI?

Which is the most common infectious agent in these patients?

\section{Methodology}

A retrospective cohort study was conducted between 1 October 2014 and 31 September 2016 in the operating room of a hospital unit in Northern Portugal. The target population of this study was composed of all patients undergoing THA in this hospital unit, corresponding to a total of 214 patients. In the period prior to the implementation of the prevention measures (from 1 October 2014 to 31 September 2015), a sample of 81 participants was obtained. After implementation (from 1 October 2015 to 31 September 2016), a sample of 133 participants was obtained. A grid was created for collecting data on the patients' age, gender, diabetes (medical diagnosis), obesity (BMI > 30), compliance with the bundles (normothermia, normoglycemia, hair removal, and preoperative showering), and SSis. Data were entered into and analyzed using IBM SPSS Statistics software, version 21.0, with an encoding number, thus respecting anonymity and data confidentiality.

For the ordinal variables, the absolute and relative frequencies were obtained. For comparing proportions, Fisher's exact test and the Chisquare test were used. The level of significance was set at 5\%.

The study obtained a favorable opinion from the Ethics Committee and was authorized by the Chairman of the Board of Directors of (Unidade Local de Saúde do Nordeste) ULSNE, as in reference no. 005873. The fundamental rights in the Nuremberg Code and the Declaration of Helsinki were respected.

\section{Results}

This sample was composed of 214 participants which were distributed by two collection periods: before and after the implementation of the bundles. Overall, $56.1 \%(n=120)$ of them were male patients aged between 35 and 87 years, with a mean age of 71.04 years and a standard deviation of 10.23 years (Table 1 ).

\section{Table 1}

Distribution of participants by period (before and after implementation of bundles), gender, and age $(n=214)$

\begin{tabular}{llccc}
\hline & & \multicolumn{3}{c}{ Implementation of Bundles } \\
\cline { 3 - 5 } & & Before $(n=81)$ & After $(n=133)$ & Total $(n=214)$ \\
\cline { 3 - 5 } Gender & $40(49.4 \%)$ & $80(60.2 \%)$ & $120(56.1 \%)$ \\
& Female & $41(50.6 \%)$ & $53(39.8 \%)$ & $94(43.9 \%)$ \\
& Total & 81 & 133 & 214 \\
\hline \multirow{3}{*}{ Age } & Minimum & 35 & 35 & 35 \\
& Maximum & 87 & 86 & 87 \\
& Mean & 70.89 & 71.14 & 71.04 \\
& Standard deviation & \pm 11.03 & \pm 9.75 & \pm 10.23 \\
\hline
\end{tabular}


With regard to risk factors, in the period before the implementation of the bundles, $16 \%(n=13)$ of participants were diabetic and $22.2 \%(n=18)$ were obese. After implementation, $21.1 \%(n=28)$ of them were di- abetic and $19.5 \%(n=26)$ were obese. Three participants in the first sampling period and seven participants in the second sampling period were found to have both conditions (Table 2).

Table 2

Distribution of participants by period (before and after implementation of bundles) and comorbidities $(n=214)$

\begin{tabular}{lccccc}
\hline & & \multicolumn{4}{c}{ Implementation of Bundles } \\
\cline { 3 - 6 } Diabetes & & Before $(n=81)$ & After $(n=133)$ & Total $(n=214)$ & $p$-value \\
\hline \multirow{2}{*}{ Obesity } & No & $68(84.0 \%)$ & $105(78.9 \%)$ & $173(80.8 \%)$ & 0.470 \\
\hline \multirow{2}{*}{ Diabetes and obesity } & Yes & $18(22.2 \%)$ & $26(19.5 \%)$ & $44(20.6 \%)$ & 0.768 \\
& No & $63(77.8 \%)$ & $107(80.5 \%)$ & $170(79.4 \%)$ & $10(4.7 \%)$ \\
\hline
\end{tabular}

As for the occurrence of SSI, 93.9\% $(n=$ 201) of participants did not develop an SSI and $6.1 \%(n=13)$ of participants developed an SSI.
In both samples, $7.4 \%(n=6)$ of participants had an SSI before the implementation of the bundles and 5.3\% $(n=7)$ had an SSI after their implementation (Table 3).

Table 3

Distribution of participants by period (before and after implementation of bundles) and SSI $(n=214)$

\begin{tabular}{ccccc}
\hline & & \multicolumn{3}{c}{ Implementation of Bundles } \\
\cline { 3 - 5 } & & Before $(n=81)$ & After $(n=133)$ & Total $(n=214)$ \\
\hline \multirow{2}{*}{ SSI } & Yes & $6(7.4 \%)$ & $7(5.3 \%)$ & $13(6.1 \%)$ \\
& No & $75(92.6 \%)$ & $126(94.7 \%)$ & $201(93.9 \%)$ \\
\hline
\end{tabular}

As for SSI location, there was a prevalence of DII, with $3.3 \%(n=7)$ of participants, followed by SII, with $1.9 \%(n=4)$ of participants, and finally OSI, with $0.9 \%(n=$ 2) of participants. Before the implementation of the bundles, no SII were found, with a predominance of DII in $6.2 \%(n=$ 5) of participants. In contrast, after the im- plementation, SII prevailed in 3\% $(n=4)$ of participants. An OSI was found in only 1 participant in both periods. With regard to the microorganism causing the infection, it was unknown in $6.8 \%(n=6)$ of participants. The most common isolated agent was staphylococcus aureus in 1.9\% $(n=4)$ of participants (Table 4). 
Table 4

Distribution of participants by period (before and after implementation of bundles) and location of SSI $(n=214)$

\begin{tabular}{lccc}
\hline & \multicolumn{3}{c}{ Implementation of bundles } \\
\cline { 2 - 4 } & Before $(n=81)$ & After $(n=133)$ & Total $(n=214)$ \\
\hline Location & & $4(3.0 \%)$ & $4(1.9 \%)$ \\
Superficial & 0 & $2(1.5 \%)$ & $7(3.3 \%)$ \\
Deep & $5(6.2 \%)$ & $1(0.8 \%)$ & $2(0.9 \%)$ \\
Organ/space & $1(1.2 \%)$ & $126(94.7 \%)$ & $201(93.9 \%)$ \\
\hline No infection & $75(92.6 \%)$ & & \\
\hline
\end{tabular}

After protocol implementation, all participants showered with chlorhexidine-impregnated sponges on day of or day before surgery; antibiotic prophylaxis was administered to all of them within 60 minutes of incision; hair was not removed in only one participant; body temperature was measured in six patients; and blood glucose levels were not controlled in nine patients. In the same period, seven participants had an SSI, although all prevention bundles were implemented (Table 5).

Table 5

Distribution of participants after implementation of bundles, showering, antibiotics, hair removal, normothermia, and blood glucose by SSI $(n=133)$

\begin{tabular}{lccc}
\hline \multirow{2}{*}{ Showering } & & \multicolumn{2}{c}{ Surgical Site Infection } \\
\cline { 3 - 4 } & & Yes & No \\
\hline \multirow{2}{*}{ Antibiotics } & Yes & $7(5.3 \%)$ & $126(94.7 \%)$ \\
& No & 0 & 0 \\
\hline \multirow{2}{*}{ Hair removal } & Yes & $7(5.3 \%)$ & $126(94.7 \%)$ \\
& No & 0 & 0 \\
\multirow{2}{*}{ Temperature } & Yes & $7(5.3 \%)$ & $125(94.7 \%)$ \\
& No & 0 & $120(100 \%)$ \\
\multirow{2}{*}{ Blood glucose } & Yes & $7(5.5 \%)$ & $6(100 \%)$ \\
& No & 0 & $117(94.4 \%)$ \\
& Yes & $7(5.6 \%)$ & $9(100 \%)$ \\
\hline
\end{tabular}

The association between the occurrence of SSI and age was statistically significant. Infections occurred in participants aged 70 or more. Although the association between the occurrence of infection and gender was not statistically significant, women had more SSIs (53.8\%) than men (46.2\%). The association between the occurrence of infection and diabetes/obesity or both was not statistically significant. The occurrence of infection was tested in obese participants with diabetes, concluding that the association was not statistically significant (Table 6). 
Table 6

Distribution of participants by age, gender, comorbidities, and SSI $(n=214)$

\begin{tabular}{|c|c|c|c|c|}
\hline & & \multicolumn{2}{|c|}{ Surgical Site Infection } & \multirow{2}{*}{$p$-value } \\
\hline & & Yes & No & \\
\hline \multirow{3}{*}{ Age } & 35 to 49 years & 0 & $7(3.5 \%)$ & \multirow{3}{*}{0.021} \\
\hline & 50 to 69 years & 0 & $67(33.3 \%)$ & \\
\hline & 70 to 86 years & $13(100 \%)$ & $127(63.2 \%)$ & \\
\hline \multirow{2}{*}{ Gender } & Male & $6(46.2 \%)$ & $114(56.7 \%)$ & \multirow{2}{*}{0.567} \\
\hline & Female & $7(53.8 \%)$ & $87(43.3 \%)$ & \\
\hline \multirow{2}{*}{ Diabetes } & Yes & $5(38.5 \%)$ & $36(17.9 \%)$ & \multirow{2}{*}{0.136} \\
\hline & No & $8(61.5 \%)$ & $165(82.1 \%)$ & \\
\hline \multirow{2}{*}{ Obesity } & Yes & $5(38.5 \%)$ & $39(19.4 \%)$ & \multirow{2}{*}{0.148} \\
\hline & No & $8(61.5 \%)$ & $162(80.6 \%)$ & \\
\hline \multirow{2}{*}{ Diabetes and obesity } & Yes & $1(7.7 \%)$ & $9(4.5 \%)$ & \multirow{2}{*}{0.473} \\
\hline & No & $12(92.3 \%)$ & $192(95.5 \%)$ & \\
\hline
\end{tabular}

\section{Discussion}

During this study, some difficulties and limitations were found related to the number of published scientific papers on this topic, thus the discussion focuses mainly on the interpretation of the collected data.

The sample was composed of 214 patients aged between 35 and 87 years; $56.1 \%$ (120) were men and $43.9 \%$ (94) were women. The mean age was 71.04 years, which corroborates the studies of Pereira, Mendoza, Couto, Ercole, and Goveia (2014), Goveia et al. (2015), and Lenza et al. (2013). In the study of Franco, Ercole, and Mattia (2015), the mean age was 62 years. The most prevalent age group in this study could be associated with the population aging in this region of Portugal, in which there were 200 older people per 100 young people in 2015 (PORDATA, 2015). According to the national census of 2011, the number of people aged over 65 years in the district of Bragança was higher than the national average by $19 \%$. According to PORDATA, in 2014, there were 17,809 women and 16,532 men in the district of Bragança, even though the results of this study show that interventions are mostly performed in men, perhaps because they carry out a lot of agricultural activities in this district, which is in line with the study of Lenza et al. (2013).

With respect to the analyzed risk factors (diabetes and obesity $), 19.2 \%(n=41)$ of the
214 participants had diabetes, 20.6\% $(n=$ 44) were obese, and $4.7 \%(n=10)$ were both obese and diabetic. The study of Pereira et al. (2014) concluded that diabetes is a risk factor for SSI because it predisposes to an impaired response to infection. Hyperglycemia can lead to alterations in the central nervous system during anesthesia (Ribeiro, Santos, Bellusse, Rezende, \& Galvão, 2013). Hyperglycemia can decrease the physiological response to bacteria. A blood glucose level $>140 \mathrm{mg} / \mathrm{dl}$ is associated with a three-time increased risk for SSI, even in patients without diabetes (Dourado, 2017). Obesity is another important risk factor for SSI because obese patients have excessive adipose tissue and decreased vascularity, which leads to longer surgeries, increased risk of abdominal wall trauma, and alterations of body temperature (Dourado, 2017).

Of the 214 participants, $6.1 \%(n=13)$ had an SSI. The most prevalent infection was the deep infection, with $3.3 \%(n=7)$, and the most common isolated infectious agent was the staphylococcus aureus, which is in line with the studies of Franco et al. (2015), Pereira et al. (2014), and the literature consulted. According to DGS (2015), the most common isolated infectious agent in SSI is staphylococcus aureus. In this study, the most common SSI was DII $(n=7)$, followed by SII $(n=4)$ and OSI $(n$ $=2$ ), which corroborates the studies of Pereira et al. (2014) and Ercole et al. (2011) and contradicts the study of Franco et al. (2015), 
in which SII prevailed. With regard to age, all participants with SSIs were older than 70 years of age, which corroborates the integrative review of Santos et al. (2015) on the incidence and risk factors for SSI and the literature review of Dourado (2017) on predisposing factors for SSI. According to these authors, older people have a poor immune function and delayed wound healing, increasing the risk of infection. Age is an intrinsic risk factor for SSI (Santos et al., 2015). This study found a statistically significant difference between the occurrence of infection and age group.

With regard to the compliance with SSI prevention bundles, after protocol implementation, 126 of the 133 participants did not develop an SSI. Although there is no statistically significant association between bundle compliance and infection, infection rates decreased by $28.4 \%$ after their implementation, DII rates decreased by $75.9 \%$, and OSI rates decreased by $33.4 \%$. Franco et al. (2015) concluded that the risk of SSI was three times higher in patients who were not washed before surgery than in those who were washed. According to Dourado (2017), the use of antibiotic prophylaxis reduces the occurrence of SSI by $5.1 \%$. SSI rates of hair removal are $20 \%$ when hair is removed more than 24 hours before surgery, $7.1 \%$ if removed within 24 hours of surgery, and $3.1 \%$ if removed immediately before surgery (Dourado, 2017).

Hypothermia is another risk factor for SSI. In this study, after implementation of the SSI prevention preventive measures, all participants who developed an SSI had complied with the SSI prevention bundle on body temperature control.

Hyperglycemia is often a problem in patients undergoing surgery and a cause of increased morbidity and mortality due to the physiological alterations in the healing process, the vascular and neuropathic complications, and the impaired immune system, thus increasing the risk for SSI. Glucose control is essential in reducing SSI rates. Blood glucose levels should be maintained between 80 and $120 \mathrm{mg} / \mathrm{dl}$ during the perioperative period (Domingos, Lida, \& Poveda, 2016).

The association between diabetes and the occurrence of SSI is not statistically significant in this study. Of the 13 participants with SSI,
$38.5 \%(n=5)$ had diabetes. The presence of diabetes in surgical patients should be investigated given that this disease impairs the response to infection (Pereira et al., 2014). Diabetes was associated with an increased risk for SSI and morbidity after different types of surgery (Pontes, Mendes, Vasconcelos, \& Batista, 2018).

The association between obesity and the occurrence of SSI is not statistically significant in this study. Of the 13 participants with SSI, 38.5\% $(n=5)$ were obese. Obesity is an important risk factor for SSI because the greater the amount of adipose tissue, the higher the likelihood of failure in tissue repair due to a decrease in oxygen levels, which may adversely influence the surgical wound healing process (Barbosa, Mendes, Amaral, \& Mattia, 2009). Oliveira, Ciosak, Ferraz, and Grinbaum (2006) found a statistically significant difference between obesity and the occurrence of SSI and that obese patients had a 3.06 times higher risk of developing an SSI. Obesity is a well-known risk factor for SSI. In patients with less than $3 \mathrm{~cm}$ of adipose tissue, the infection rate was $6.2 \%$, while among those who had more than $3.5 \mathrm{~cm}$ of adipose tissue, the SSI rate was $20 \%$ because the tissue is poorly vascularized and surgeries are longer, increasing the probability of abdominal wall trauma and increasing the difficulty to regulate the body's temperature properly (Oliveira et al., 2006).

\section{Conclusion}

Based on these results, it can be concluded that the SSI rate decreased by $28.4 \%$ after bundle implementation. In terms of percentages, DII rates decreased by $75.9 \%$ and OSI by $33.4 \%$. The most prevalent type of infection was the deep infection and the most common isolated infectious agent was the staphylococcus aureus. A statistically significant association was found between age and the development of SSI.

Taking into account the high-risk factors for SSI, the need for health professionals to adopt SSI prevention and control measures should be considered.

The importance of a thorough skin preparation should also be highlighted given the microorganisms identified in this study.

Based on these results, we suggest that the 
population should be educated about how to prevent the modifiable intrinsic risk factors for SSIs. We also suggest that healthcare providers should be more aware of the risks for SSI so as to provide better care and reduce both economic costs and patient suffering. A large number of SSIs can be avoided through small interventions and multidisciplinary surveillance and commitment. The more the information on risk and protective factors is produced and disseminated, the greater the potential to reduce SSI rates. Nurses play a key in this context, establishing the link between the patients and the professionals involved, and must be aware and updated on information concerning SSIs.

\section{References}

Barbosa, M. H., Mendes, M. A., Amaral, J. B., \& Mattia, L. A. (2009). Ocorrência de infecção de sítio cirúrgico de um hospital universitário de Minas Gerais. Revista Mineira de Enfermagem, 13(3), 423-427. doi: S1415-27622009000300015

Centers for Disease Control and Prevention. (2017). Surgical Site Infection (SSI) Event. Retrieved from https:// www.cdc.gov/

Direção-Geral da Saúde. (2017). Programa de Prevenção e Controlo de Infeçóes e de Resistência aos Antimicrobianos. Retrieved from https://www.dgs.pt/

Direção-Geral da Saúde. (2015). Norma 020/2015. Retrieved from https://www.dgs.pt/

Domingos, M. H. D., Lida, L. I., \& Poveda, V. B. (2016). Estratégias de controle glicêmico e a ocorrência de infecção do sítio cirúrgico: Revisão sistemática. Revista da Escola de Enfermagem da USP, 50(5), 868-874. doi: 10.1590/S0080-623420160000600022

Dourado, E. D. (2017). Fatores predisponentes de infecção de sítio cirúrgico: Uma revisão da literatura. Trabalho não publicado. Retrieved from https://repositorio.uniceub.br/jspui/bitstream/235/11749/1/21395477.pdf

Ercole, F. F., Franco, L. M., Macieira, T. G., Wenceslau, L. C., Resende, H. I., \& Chianca, T. C. (2011). Risco para infecçâo de sítio cirúrgico em pacientes submetidos a cirurgias ortopédicas. Revista Latino-Americana de Enfermagem, 19(6). Retrieved from http://www. scielo.br/pdf/rlae/v19n6/pt_12.pdf

Fundação Calouste Gulbenkian. (2015). Programa stop infeçâo hospitalar. Retrieved from http://www.stopinfecaohospitalar.com/
Franco, L. M., Ercole, F. F., \& Mattia, A. D. (2015). Infecção cirúrgica em pacientes submetidos a cirurgia ortopédica com implante. Revista Sobecc, 20(3), 163-170. doi: 10.5327/Z1414-4425201500030007

Goveia, V. R., Mendoza, I. Y., Couto, B. R., Ferreira, J. A., Paiva, E. B., Guimarães, G. L., \& Stoianoff, M. A. (2015). Perfil dos pacientes submetidos à artroplastia do quadril em hospital de ensino. Revista do Colégio Brasileiro de Cirurgiōes, 42(2), 106-110. doi: 10.1590/0100-69912015002007

Lenza, M., Ferraz, S. D., Viola, D. C., Filho, R. J., Neto, M. C., \& Ferretti, M. (2013). Epidemiologia da artroplastia total de quadril e de joelho: Estudo transversal. Revista Einstein, 11(2), 197-202. doi: 10.1590/ S1679-45082013000200011

Oliveira, A. C., Ciosak, S. I., Ferraz, E. M., \& Grinbaum, R. S. (2006). Infecção da ferida cirúrgica em pacientes submetidos à cirurgia. Revista Médica de Minas Gerais, 16(1), 18-23. Retrieved from http://rmmg. org/artigo/detalhes/246\#

Pereira, B. R., Mendoza, I. Y., Couto, B. R., Ercole, F. F., \& Goveia, V. R. (2014). Artroplastia do quadril: Prevenção de infecção do sítio cirúrgico. Revista Sobecc, 19(4), 181-187. doi: 10.5327/Z14144425201400040002

Pontes, J. P., Mendes, F. F., Vasconcelos, M. M., \& Batista, N. R. (2018). Avaliação e manejo perioperatório de pacientes com diabetes melito: Um desafio para o anestesiologista. Brazilian Journal of Anesthesiology, 68(1), 75-86. doi: 10.1016/j.bjan.2017.04.017

PORDATA. (2015). Retrato de Portugal. Retrieved from https://www.pordata.pt/Municipios/Retratos/2017/ Retrato+de+Portugal-54

Ribeiro, J. C., Santos, C. B., Bellusse, G. C., Rezende, V. D., \& Galvão, C. M. (2013). Ocorrência e fatores de risco para infecção de sítio cirúrgico em cirurgias ortopédicas. Acta Paulista de Enfermagem, 6(4), 353359. doi: 10.1590/S0103-21002013000400009

Santos, G. C., Baylão, A. F., Borges, S. C., Silva, L. A., Batista, M. H., \& Leite, G.R. (2015). Incidência e fatores de risco de infecção de sítio cirúrgico: Revisão integrativa. Revista Eletrônica Graduação/Pós-Graduação em Educação UFG/REJ, 11(1). doi: 10.5216/rir. v11i1.34142

Shuman, E. K., Urquhart, A., \& Malani, P. N. (2012). Management and prevention of prosthetic joint infection. Infection Disease Clinical North America, 26(1), 29-39. doi: 10.1016/j.idc.2011.09.011 